\title{
Sivas Kongresi Öncesinde Vilayetin Asayiş Durumuna Dair Bir Rapor
}

\author{
Yrd. Doç.Dr. Nurşen GÖK*
}

\begin{abstract}
$\ddot{O Z Z E T}$
Mondros Ateşkes Anlaşması sonrasında Anadolu'da ortaya çıkan direniş sürecinde en önemli adımlardan birini oluşturan Sivas Kongresi öncesinde, vilâyetin asayis durumunu ortaya koyan ve bu konuda çözüm önerileri getiren bir teftis raporu de ğerlendirilmektedir. Bölgede faaliyet gösteren Asker kaçakları ile Rum, Ermeni, Türk; Gürcü ve Çerkez gruplarından oluşan ve bir bölümü siyasi amaçlı bir bölümü kendi menfaatlerini sağlamak üzere hareket eden çeteler bölgedeki en büyük asayiş sorununu ortaya çıkarmaktadırlar. Asayiş sorunlarının çözümü için, hükümet tarafindan Anadolu'ya teftiş amaçlı müfettişler gönderilmiştir.

Teftişte karşılaşılan durum rapor haline getirilmiş ve hükümete sunulmuştur. Özellikle asker kaçakları, çeşitli etnik gruplara mensup olanların çıkardıkları olaylara raporda yer verilmis bulunmaktadır.
\end{abstract}

Anahtar Kelimeler: Asayiş, Sivas Kongresi, Anadolu, Çete Faaliyetleri.

\section{ABSTRACT}

Before the Congress of Sivas, an investigation report about the law and order in the city of Sivas was submitted to the Ministry of Internal Affairs. In this paper we will deal with this report in which military fugitives, various groups; such as organized crime groups and partisans which were composed of different ethnic back grounds such as Greek, Armenian, Turkish; Georgians and Circassian; and also had different aims on the one hand for the political causes and on the other hand providing interest were the main problems of public peace in Sivas. In order to solve these public security problems inspectors were dispatched. The case during the tour of inspection were reported and submitted to the government. The issue of military figutives, events caused by various ethnic groups were discussed in the report.

Key Words: Public security, Congress of Sivas, Anatolia, Criminal Activities

\footnotetext{
${ }^{*}$ Zonguldak Kara Elmas Üniversitesi Fen Edebiyat Fakültesi Tarih Bölümü
} 
Osmanlı İmparatorluğu'nun Birinci Dünya Savaşı'ndan yenilgiyle çıktığını belgeleyen Mondros Ateşkes Anlaşması sonrasında, toprakları İtilaf Devletleri'nin işgali altına girdi. Musul İngilizler, Adana, Antep, Maraş ve Urfa önce İngilizler sonra Fransızlar, Antalya ve çevresi İtalyanlar, İzmir başta olmak üzere Batı Anadolu bölgesi Yunanlılar tarafından işgal edildi.

Büyük bir bölümü işgal altında olan ve siyasi istikrarın bulunmadığı ülkede güvenlik ve asayiş sorunlarıyla karşılaşılması kaçınılmazdı. Bu dönemde Anadolu'nun birçok bölgesinde olduğu gibi Sivas gibi büyük bir vilayette $^{1}$ de güvenliğin sağlanmasında sorunlar yaşandığı görülmektedir.

Vilayetin asayişle ilgili en önemli sorununu asker kaçaklarından, Müslüman, Rum, Ermeni, Gürcü, Çerkez unsurlardan oluşan bazen Gürcü ve Türklerin birlikte hareket ettikleri çeteler oluşturmaktaydı. Bu çetelerden bir bölümü soygun, adam kaçırmak, gasp gibi adi suçlar işlerken, özellikle Rumlardan oluşan çetelerin faaliyetleri siyasi bir nitelik göstermekteydi.

Bölgede meydana gelen adi şekavet olaylarının temelinde mali istikrarsız ortamın aç bıraktığı insanların sayısındaki artış olmalıdır. Özellikle Balkan ve Trablusgarp savaşlarından sonra ülke genelinde gıda ve ihtiyaç maddeleri fiyatlarının aşırı derecede artması nedeniyle artan soygun ve hırsızlığa yönelik olaylar ${ }^{2}$ bu dönemde de devam etmekteydi. Etraflarına özellikle asker kaçaklarını toplayarak dehşet saçan çeteler, geçimlerini köylere yaptıkları baskınlarla sağlamaktaydılar ${ }^{3}$.

Siyasi çete faaliyetlerinin eksenini ise Rumların Pontus hükümetini kurmak emelleri oluşturmaktaydı. Bilindiği gibi Sivas, ayrılıkçı Ermenilerin üzerinde bağımsız bir devlet kurmaya çalıştıkları topraklardandı. Aynı zamanda Rumlar Osmanlı Devleti topraklarından, Zonguldak'tan Batum'a kadar olan kıyıları ve Trabzon, Ordu, Giresun, Canik, Sinop, Zonguldak, Tokat, Amasya, Çorum, Yozgat ve Sivas'ı içine alan bir toprak parçasını ayırarak, bu toprak parçası üzerinde Pontus adı altında bir cumhuriyet kurmak istiyorlard1 ${ }^{4}$.

${ }^{1} 1913$ yılında Sivas Vilâyeti'nin; Sivas, Tokat, Amasya, Karahisar-1 Şârkî olmak üzere toplam dört sancağı, 28 kazâsı bulunmaktadır. Ramazan Özey, "20. Yüzyılın Başlarında Sivas'ın Tarihi Coğrafyası" Cumhuriyet'in 80. Yılında Sivas Sempozyumu (15-17 Mayıs 2003, Sivas), Sivas, 2003, s.135.

2 Osman Köse, "Canik’te Asayiş", 19 Mayıs ve Milli Mücadelede Samsun Sempozyumu (20-22 Mayls 1999), Samsun, 2000, s.248.

3 İncelediğimiz dönemde Sivas Vilâyeti, 75 bin kadarının Rum olduğu toplam nüfusu 800 bin dolaylarında büyük bir vilayetti. Kalabalık nüfusu barındırmasına karşın, tahıl ekimine ayrılan toprakların verimsiz olduğu, ticaret ve sanayinin gelişmediği vilâyette ekonomik yaşam sönüktü. Bütün bu olgular bu bölgede eşkıyalığı sıradan bir olay durumuna getirmişti. Yoksul köylüler, içine düştükleri çaresizlik nedeniyle hem eşkıyalığa özeniyor, hem kendilerini de hedef alan soygun olaylarından yakınıyorlardı. Yurt Ansiklopedisi, Cilt 9 , İstanbul 1982- 83, s.6865.

${ }^{4}$ Pontus Meselesi, Hazırlayan: Yılmaz Kurt, TBMM yayınları, Ankara, 1995, s.396. 
Canik merkez olmak üzere Pontus idealiyle hareket eden Rum çetelerinin faaliyet gösterdiği alanlardan birisi de Sivas vilayetiydi. Özellikle Canik'le sınır olması nedeniyle Amasya ve Tokat sancaklarında çetecilik ve siyasi amaçlı örgütler kurulup faaliyet göstermekteydiler ${ }^{5}$.

Mondros Ateşkes Anlaşmasından sonra orduların küçültülmüş olması, silahların önemli bir kısmının elden çıkması nedeniyle hükümetin elinde halkı çetelere karşı koruyacak yeterli kuvvet bulunmamaktaydı.

Ayrılıkçı grupların planlarını, İtilaf Devletleri de destekliyordu. Nitekim Mondros Mütareke Antlaşması'nın 24. maddesi, İtilaf Devletleri'ne Sivas Vilâyetinin de bulunduğu ve "Ermeni Vilayetleri" olarak anılan vilâyât-1 sitte sınırları içinde çıkabilecek bir kargaşalığa müdahale etme hakkı tanıyordu ${ }^{6}$. Kimi Rum ve Ermeni çeteleri de, büyük devletlere müdahale ortamı hazırlama çabası içindeydiler. Sivas Vilâyeti sınırları içinde de özellikle Hafik, Şarkışla ve Aziziye kazalarında, silahlı Rum ve Ermeni çeteleri çok sık köy baskınları düzenliyor köylüleri yıldırmaya çalışıyorlardı ${ }^{7}$.

Ülke genelinde görülen asayișle ilgili sorunlar İstanbul Hükümeti tarafından da bilinmekteydi. Olanaklar el verdiğince çözüm aranmaktaydı. Asayiş sorunlarına çözüm ararken, vilâyetlere teftiş amaçlı görevlendirmeler yapılmış ve bu görevliler teftiş sırasındaki görüş ve düşüncelerini rapor şeklinde hükümete sunmuşlardır. Birçok raporda raporu hazırlayanın adı ve unvanı yer verilmiștir, ancak Sivas Vilâyeti'ne ilișkin elimizde bulunan 26 Haziran 1919 (26 Haziran 1335) tarihli raporda raporun kimin tarafından yazıldığı belirtilmemiştir. Bu durum Vilayet'e ilişkin bu raporun elimizde şifre çözümü bir kopyasının bulunmasından kaynaklanmaktadır. Bununla birlikte rapor 1919 yılında Sivas Vilayetinde karşılaşılan sorunları özellikle güvenlikle ilgili olanları saptaması ve olası çözüm çarelerini göstermesi bakımından dikkat çekicidir. Bölgenin sosyal tarihi açısından katkı sağlayacak nitelikteki bu belgeyi yayınlamakta yarar görmekteyiz. Belge Ankara Üniversitesi Türk İnkılâp Tarihi Enstitüsü (TİTE) arşivinde Kutu: 16 Gömlek: 83 Belge: 83 numarasıyla kayıtlıdır ${ }^{8}$. Söz konusu raporun hazırlanmadan önce görüldü̆ğunü sandığımız, 11-26 Haziran 1919 tarihleri arasında Sivas Vilâyeti livâ, kazâ ve köylerinde meydana gelen asayişi

${ }^{5}$ Atatürk tarafından 5 Haziran 1919 tarihinde Havza'dan gönderilen raporda Amasya Livası sınırları içerisinde 21, Tokat'ın Canik'le sınır olan Erbaa ve Niksar kazâlarında ise 5 Rum çetesinin faaliyet gösterdiği belirtilmektedir. Atatürk'le İlgili Arşiv Belgeleri, Başbakanlık Osmanlı Arşivi Daire Başkanlığı Yayını, Ankara, 1982, s.34- 36. (Belge: 34); Rum ceteleri tarafından Amasya ve Tokat sancaklarında 1916 yılından itibaren gerçekleştirilen olaylar için bkz. age, s.262-327

${ }^{6}$ Şerafettin Turan, Türk Devrim Tarihi, 1. Kitap: Imparatorluğun Çöküşünden Ulusal Direnişe, Ankara, 1991, s.68.

${ }^{7}$ Yurt Ansiklopedisi, Cilt 9, İstanbul 1982-83, s.6865.

${ }^{8}$ EK.I. 
bozucu faaliyetlere ilișkin ilgili mülki ve askeri makamlardan alınan bilgileri içeren belgeler ise TİTE Arşivi K.19 B.72, 72 (1.2.3) de kayıtlıdır?.

Rapor edilen olayların ferdi değil çete faaliyetleri olduğu görülmektedir. Sivas Vilâyeti'nin en önemli asayiş sorunu olduğu belirtilen çete faaliyetleri adi ve siyâsî olmak üzere iki gruba ayrılmıştır. Türk, Çerkez ve Gürcülerden oluşan çetelerin şekavetlerini kendi şahsi menfaatleri sağlamak için sürdürdükleri, soygun, gasp, adam öldürmek gibi adi suçlar işledikleri açıklanmaktadır. Bu tür faaliyetlerin temelinde daha çok açlığın yattığ 1 anlaşılmaktadır. Rum çetelerinin faaliyetleri ise daha çok siyasi olarak nitelendirilmiştir.

Sivas Vilâyetinin Amasya ve Tokat livâlarında faaliyet gösteren Rum çetelerinin daha çok siyasi amaçla hareket etmekle birlikte adi suçlar da işledikleri anlaşılmaktadır. Bu livâların kaza ve köylerinde aynı zamanda Rum çeteleriyle karşılaştırıldıklarında oldukça küçük dört-beş kişilik gruplardan oluşan Çerkez, Gürcü, Türk çeteleri de yol kesmek, gasp, adam soymak gibi adi suçlar işleyerek iç huzurun bozulmasına neden olmaktadırlar. Merkez livâ Sivas'ta kalabalık gruplardan oluşan Ermeni çeteleri bulunmaktadır. Bu çeteler incelediğimiz tarihte faaliyetlerini siyasi amaçla değil soygun ve gasp amaciyla sürdürmektedirler. Soygun, gasp gibi adi suçların daha çok kırsal bölgede gerçekleştiği görülmektedir.

Sivas vilâyetine bağlı livâ mutasarrıflıkları, kaymakamlıklar, nahiye müdürleri tarafından verilen bilgilerde vilâyette 11 Haziran - 26 Haziran tarihleri arasında şekavet yapmakta olan adi ve siyasi eşkıya çeteleri şu şekilde gösterilmiştir ${ }^{10}$ :

Amasya Merkez Sancă̆g: Varay Nahiyesinden Çerkez İbrahim'in başkanlığında beş ve Fındıklı karyesinden Rum Etnas'ın başkanlığında yirmi ve Karaağaç karyeli Kostanik başkanlığında yirmi ve Abacı karyeli Lefter'in başkanlığında yirmi kişiden oluşan dört eşkıya çetesi bulunmaktadır.

Merzifon Kazası: Gürcü Ahmet'in başkanlığı altında Gürcü ve Türk olarak altı kişilik bir çete mevcuttur.

Gümüşhacıköy Kazası: Maden karyesinden Hapo ve küçük Hapo ve Kadıköylü Angelos başkanlıkları altında kırk kişiden fazla bir eşkıya çetesi mevcuttur.

Havza Kazası: Havzalı Ender Payan'ın başkanlığı altında on beş kişiden oluşan bir Rum Çetesi ve Lâdikli Sokrat'ın başkanlığ 1 altında yirmi kişiden oluşan bir eşkıya çetesi bulunmaktadır.

\footnotetext{
${ }^{9}$ EK.II.

${ }^{10}$ TITE Arşivi K.19 B.72, 72-1, 72-2, 72-3.
} 
Köprü Kazası: Ersedok Karyeli İlya ve Neyan'ın başkanlığında on sekiz ve Karlık karyeli Padlos'un başkanlığında yirmi-otuz kişiden oluşan eşkiya çeteleri mevcuttur.

Lâdik Kazası: Lâdik Kazası dâhilinde yüzde yirmi İslâm ve geri kalanı Rum olmak üzere iki yüz elli ve üç yüz mevcutlu eşkıya çeteleri bulunmaktadır.

Tokat: Tokat'ın merkez livâsında adi suçlular dışında adi ve siyasi eşkıya çetesi bulunmamakla beraber Erbaa kâzası dâhilinde eşkıya-yı müste'minden Hacıbey karyeli Lefter ve Kozlıcaalan karyeli Estil ve Kırkharman karyeli Entaş ve Karamoklu Çakır ve İkipınarlı diğer Entaş'ın başkanlıklarında beş Rum çetesi bulunmaktadır. Bunların amaçları siyasi olmakla beraber faaliyette olmayıp fırsat buldukça gelen geçene saldırmak gibi adi suçlar işlemektedirler.

Gürün Kazası: Gürün kazâsı bölgesinde adi ve siyasi eşkıya çetesi bulunmamaktadır. Ancak kazânın Elbistan'la sınır olması nedeniyle Elbistan soyguncuları bazen Gürün bölgesine saldırmaktadır.

Karahisar-ı Şârkî Sancă̆ı: Mutasarrıflıktan alınan bilgiye göre Karahisar-ı Şârkî livası bölgesinde adi ve siyasi eşkıya çeteleri bulunmamaktadır.

Hıdırnallı ve Ulaş nahiyeleri dâhilinde siyasi ve adi çeteler bulunmamaktadir.

İlbeğlü Nahiyesi: Nahiye dâhilinde siyasi ve adi çete bulunmamaktadır. Bununla birlikte ara sıra üç beş kişiden oluşan adi çeteler ortaya çıkmakta ve köylere saldırmaktadırlar.

Yenihan Kazası: kaza dâhilinde siyasi eşkıya çeteleri bulunmamakla birlikte bazen Zile ve Maden kazaları bölgesine giderek soygunculuk yapan dört beş kişilik Yeni Köylü Kara Mustafa Çetesi vardır. Bu çete daha sonra Amasya hududuna geçmiştir.

Hafik Kazası: Kaza dâhilinde tehcirden dönmüş olan Ermenilerden oluşan yirmi beş ve otuz kişilik bir eşkıya çetesi bulunmaktadır. Bu çete ara sıra gelen geçene saldırmakta ve para ve eşyalarını gasp etmektedir. Göktepe bölgesinde postaya taarruz ederek elli bin kuruşu geçen emaneti gasp etmiş ve terhis olmuş askerlerden beş kişiyi Canik ile Zara arasında feci bir şekilde katletmişlerdir. Bunlara civar köyler ahalisinden bazı İslamların yataklık ettikleri ifade edilmektedir.

Darende Kazası: Darende Kazası dâhilinde sürekli faaliyet gösteren eşkıya bulunmamaktadır. Ancak kaza jandarma mevcudu ara sıra gerçekleşen adi suçların faillerini ele geçirmeye uygun değildir. 
Tenos Kazası: Boğazlıyan kazasının Çat karyesi ...nde saklanan elli kişiden oluşan Desmo Ebil'in başkanlığında bir Ermeni çetesi bulunmaktadır. Bu çete siyasi bir amaca dayanmamakla beraber ara sıra Tenos kazasına bağlı köylere saldırmakta olduklarından ele geçirilmeleri için birkaç defa çeşitli mahallerde müfrezeler gönderilmiş, ancak saklandıkları ormanın sarp olması nedeniyle yakalanmaları sağlanamamıştır.

Divriği Kazası: Divriği Kazası dâhilinde siyasi çete bulunmamaktadır. Zara Kazası'nda Karacaviran Karyesi'nin Kasım Oğlu İsmail ve Süleyman oğlu İzzet ve Divrik'in Hamuç karyesi'nden Ali oğlu Ali ve Ziver Naci Hüseyin ve üç dört refikasıyla Zara ve Divriği Torbaçay kazaları arasında eşkıyalık yapmaktadırlar. Yakalanmaları için yirmi mevcutlu bir müfreze gönderilmiştir.

Kangal Kazası: Kangal mıntıkasında adi ve siyasi eşkıya çeteleri bulunmamaktadır.

Mülki ve askeri yetkililer, jandarma mevcudunun eksikliğinin tamamlanması üzerinde ısrarla durmuşlardır. Jandarma veya nizamiye müfrezeleriyle çarpışma olması durumunda civar Rum köylerinde eli silah tutan Rumlar hemen çarpışmaya katılmaları nedeniyle, üstün kuvvet karşısında kalan müfrezeler bunları tenkil edememekte ve çarpışma kendileri açısından başarısızlıkla sonuçlanmaktadır. Özellikle Rum çetelerinin hareket alanı olan Amasya ve Tokat'ta kuvvetlerin artırılması gerekmektedir. Amasya taburuna altı yüz mevcutlu bir nizamiye taburunun verilmesi, Erbaa kazâsı bölgesinde bulunan jandarma karakollarının çoğaltılması ve Erbaa jandarma bölüğü mevcuduna üç subay, on bir piyade ve kırk iki süvari neferinin ilave edilmesi, Erbaa kâzasıya sınırı bulunan bazı nahiyelerin merkezlerinde karakol kurulmak üzere dört bölükten oluşan Tokat jandarma taburunun beş bölüğe çıkarılması gerekmektedir. Ayrıca Rus, Osmanlı, Avusturya, Alman ve İngiliz tüfekleriyle donanmış olan eşkıya çetelerinin ellerinde bulunan silahlar, asker elinde bulunan silahlardan çok daha iyi durumdadır. Asker elinde bulunan silahların küçük mavzerlerle değiştirilmesi önerilmiştir.

Jandarma kumandanlarının muktedir ve mektepli kişiler arasından seçilmesi, talim ve terbiye için jandarma efrad mektebinin açılması, bazı bölgelerde ise yerli jandarmanın tamamen değiştirilmesi gerekliliği belirtilmektedir.

Asker ailelerinin iaşelerinin temini, subay ve memur maaşlarının artırılması ve düzenli ödenmesi, Levazım eksiklerinin tamamlanması, telefon tellerinin tamiri gerekliliği verilen bilgilerden anlaşılmaktadır. 
Sivas Vilâyeti dâhilinde hareket eden çetelerden 11 Haziran 1919 tarihinden 26 Ağustos 1919 tarihine kadar ele geçirilenlerin sayısı şu şekilde belirtilmiştir:

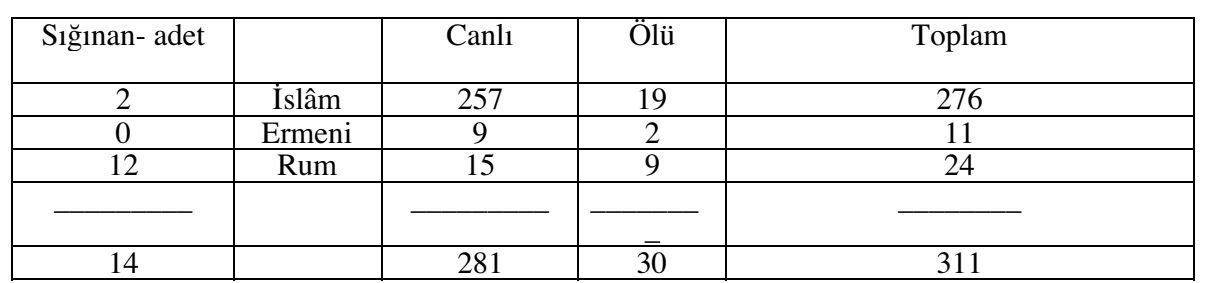

Bütün bu bilgiler 1şı̆̆ında Dâhiliye Nezareti'ne sunulan Sivas Vilayetine ilişkin 26 Haziran 1919 (1335) tarihli bu teftiş raporunda Sivas Vilayeti asayişine dair şu değerlendirilme yapılmıştır:

Adi olaylardan asayişin en çok bozuk olduğu yer Amasya sancağıdır. Bu livanın müstakil Canik sancağıyla sınır olmasından dolayı, burada çok sayıda siyasi Rum çeteleri mevcut olduğu gibi silahlı asker kaçaklarından oluşan İslam çeteleri bulunmaktadır. Nüfusun katli, gasp ve soygun, dağa adam kaldırmak, hapishaneden firar bu livada sıradan günlük olaylar şeklinde gelişmektedir.

Asayişin sağlanması konusunda mülki ve askeri yetkililerin önlem almaktaki ihmalleri söz konusu olmakla birlikte, asayişsizliğin sürmeye devam etmesindeki en önemli neden olarak inzibat ve takip araçlarının nitelik ve nicelik bakımından yetersizlikleri gösterilmektedir. Müfettişin bölgede bulunduğu on dört gün içerisinde meydana gelen olaylarda, faillerin takip ve yakalanması için yapılan tebligata rağmen emrin yerine getirilmesinde kayıtsılılıkla karşılaşılmıştır. Bu duruma yetkililerin yanıtı; jandarma kuvvetlerinin yetersiz sayıda olduğu, iki-üç aydan beri alınamayan maaşların görevin yerine getirilmesinde şevkleri kırdığ 1 şeklinde olmuştur. Müfettişin tespiti jandarma kuvvetlerinin sayıca eksik olduğu yönündedir. Vilâyet jandarma alayı kadrosu esası itibariyle 1452 piyade ve 480 süvariden ibaret olmakla birlikte içinde bulunulan tarihte elde bulunan mevcut 926 piyade ve 350 süvariden ibarettir. Ayrıca bunların büyük bir bölümü hiçbir işe yaramayan bakaya ve firari efrad ile kısmen gönüllülerden oluşmaktadır. $\mathrm{Bu}$ mevcudun bir bölümü hapishane ve posta muhafızlığı, yazı işleri gibi çeşitli hizmetlere ayrıldı̆̆ında mevcut 523 piyade ve 205 süvari kalmaktadır.

Belirtilen kabiliyette ve sayıdaki askerle yoğun bir nüfusu 3 liva, kaza ve nahiyeleri kapsayan Sivas Vilâyeti'nin düzen ve asayişinin sağlanmasının mümkün olmadığı, kadronun tam olması durumunda bile düzen ve asayişin 
ancak normal şartlarda mümkün olduğu raporda belirtilmektedir. Sivas dâhilinde ise gerek açlık gerekse türlü emel ve amaçlarla kargaşalıktan yararlanmak isteyen muhtelif amillerin etkisiyle şirazeden çıkarak olağanüstü bir durum kazanmış olan mahallerde bu kadro ile iş görülmek mümkün olamayacaktır.

Duruma çözüm önerisi olarak, sükûnet ve asayişin bulunduğu sanılan Kastamonu, Ankara, Konya gibi civar vilayetlerden alınacak kıymetli efrad ile kadro gereksiniminin sağlanması, işe yarar subay ve efrad sağlayabilmek için maaşların düzenli olarak ödenmesi, kadronun genişletilmesinin mümkün olamaması durumunda hali hazırda eksiğin tamamlanması için takip işlerinde deneyim kazanmış yetenekli subaylar kumandasında tam mevcutlu iki bölük askerin devamlı olarak jandarmaya yedek kuvvet olarak ilavesi önerilmektedir. Bu durumda asayiş meselesinin başarıla biteceğini ve aksi takdirde mevcut imkânlarla hiçbir şey yapılamayacağı belirtilmektedir. Asker meselesi için kolorduya veya mülhakattaki tümenlere başvurulması mümkün görülmekle birlikte, askerin terhisinden dolayı bunların mevcudunun çok az olması ve o ana kadar gerekli yararın sağlanamaması nedeniyle önerilmemektedir.

Mondros Ateşkesi'yle ordunun büyük bir bölümünün terhis edilmesi nedeniyle yeterli jandarma kuvveti bulunmaması ülke genelinde olduğu gibi Sivas Vilayeti dâhilinde de asayişin sağlanmasında karşılaşılan önemli engel olduğu açıktır. Yeterli jandarma kuvvetinin bulunmamasının yanı sıra, asker kaçaklarının varlığı asayişi tehdit eden önemli unsurlardandır. 1914 sonrasında bölge asayişini etkileyen en önemli gelişme olan "Pontus Meselesi" ne dayanan asayiş bozucu çete faaliyetleri devam etmektedir. Ermeni çeteleri bulunmakla birlikte bunların daha çok adi suçlara karışmaktadırlar. Ermeni ve Rum çeteleri kalabalık gruplardan oluşmaktadır. Türk, Gürcü, Çerkez çeteleri üç-beş kişilik küçük gruplar halindedir ve siyasi her hangi bir talepleri olmayıp tamamen şahsi çıkarlarını sağlama amaçlı hareket etmektedirler.

\section{KAYNAKÇA}

Ankara Üniversitesi Türk İnkılap Tarihi Enstitüsü Arşivi (TíTE Arşivi) Kutu (K) 16 Gömlek (G) 8 Belge (B) 83 .

TİTE Arşivi K.19 B.72, 72-1, 72-2, 72-3.

Yurt Ansiklopedisi, Cilt 9, İstanbul 1982- 83.

Atatürk'le İlgili Arşiv Belgeleri, Başbakanlık Osmanlı Arşivi Daire Başkanlığı Yayını, Ankara, 1982 
Köse, Osman, "Canik'te Asayiş", 19 Mayıs ve Milli Mücadelede Samsun Seтроzуити (20-22 Mayıs 1999), Samsun, 2000.

Pontus Meselesi, Hazırlayan: Yılmaz Kurt, TBMM yayınları, Ankara, 1995.

Özey, Ramazan, "20. Yüzyılın Başlarında Sivas’ın Tarihi Coğrafyası" Cumhuriyet'in 80. Yılında Sivas Sempozyumu (15-17 Mayıs 2003, Sivas), Sivas, 2003.

Turan, Şerafettin, Türk Devrim Tarihi, 1. Kitap: İmparatorluğun Çöküşünden Ulusal Direnişe, Ankara, 1991. 


\section{EK.I}

TİTE Arşivi K. 19 G.72 B. 72, 72(1,2,3)

Sivas Vilâyeti dâhilinde icrâ-yı şekavet etmekte bulunan adi siyâsî eşkıyâ çetelerinin mikdarına ait malumat ber-vech-i zîrdir:

Amasya Merkez Sancă̆g: Mutasarrıflıktan alınan tahrîrât-ı cevâbiye hulâsası Varay nâhiyesinden Çerkes İbrahim'in riyâseti tahtında beş ve Fındıklı karyesinden Rum Etnas'ın riyâseti tahtında yirmi ve Karaă̆ac Karyeli Kostanik riyâseti tahtında yirmi ve Abacı karyeli Lefter'in riyâseti tahtında yirmi kişiden mürekkeb dört eşkıyâ çetesinin mevcûd bulunduğu .

Merzifon Kazâsı: Gürcü Ahmed'in riyâseti tahtında Gürcü ve Türk olarak altı kişilik bir çetenin mevcûd bulundu ğu.

Gümüşhacıköy Kazâsı: Maden karyesinden Hapo ve Küçük Hapo Ve Kadıköylü Angelos'un riyâsetleri tahtında kırk kişiyi mütecâviz bir eşkıyâ çetesi mevcûd olub dehâletlerinin teminine çalışılmakta olduğu .

Havza Kazâsı: Havzalı Ender Payan'ın riyâseti altında on beş kişiden mürekkeb bir Rum çetesi mevcûd bulunduğu.

Havza Kazâsı: Ladikli Sokrat'ın yirmi kişiden mürekkeb bir eşkıyâ çetesinin riyâseti tahtında bulunduğu.

Köprü Kazâsı: Ersedok karyeli İlya ve Neyan'ın riyâsetleri altında on sekiz ve Karlık karyeli Padlos'un riyâseti altında yirmi otuz kişiden mürekkeb eşklyâ çeteleri mevcûd bulunduğu.

Lâdik Kazâsı: Ladik Kazâsı dâhilinde yüzde yirmi İslâm ve mütebâkîsi Rum olmak üzere iki yüz elli ve üç yüz mevcûdlu eşklyâ çeteleri bulunduğu.

Eşkıyâ-yı merkûmenin esbâb-ı şekavetleriyle der-dest ve tenkîlleri için ittihazı lazım gelen tedâbir

Bâlâda mikdar ve milletleri gösterilen eşkıyâ çeteleri Rus, Osmanlı, Avusturya ve Alman ve Ingiliz tüfekleriyle mücehhez olub bunlardan Türk ve Çerkes ve Gürcü şakilerinin maksad-ı şekavetleri menfaat-i şahsiyelerini temin için soygunculuk ve hayvan gasb etmek gibi vakayi'-i adiyeden ibaret olduğu Rum çetelerinin maksadları ecânibe karşı âsâyiş-i memleketi muhtell göstermek için İslam köylerine tecâvüz ve bir çok emvâl hayvanât ve eşya gasb ve katl ifâ etmekte olub jandarma veya nizâmiye müfrezeleriyle müsâdeme vukuunda civar Rum köylerinde eli silah tutan Rumlar hemen toplanarak müsâdemeye iştirak etmekte olmaları üzerine fâik ve mütekabil kuvvet karşısında kalan müfrezeler eşirrâ-yı merkûmeyi tenkîl edemeyerek müsâdemenin muvaffaklyetsizlikle neticelenmekte olduğu ve bunların bir an evvel der-dest ve tedmîri tamamen boş bulunan süvari kadrosuyla kısmen boş bulunan piyâde jandarma kadrolarının ikmâline ve Amasya livâsı dâhilindeki 
nizâmiye kuvvetlerinin tezyîdine vâ-beste bulunduğu Amasya Mutasarrıflı̆̆ından bildirilmiştir.

Tokad: Cevâben alınan tahrîrâtda Tokad'ın merkez livâsında cerâim-i adiye fâillerinden başka adi ve siyâsî eşkıyâ çetesi yok ise de Erbaaa kazâsı dâhilinde eşkıyâ-yı müste'minden Hacıbe ğ karyeli Lefter ve Kozlıcaalan karyeli Estil ve Kırkharman karyeli Entaş ve Karamoklu Çakır ve İkipınarlı diğer Entaş'ın riyâsetleri altında beş Rum çetesi mevcûd olub maksadları siyâsî ise de el-yevm hal$i$ faaliyetde olmayub firsat buldukca mârrin ve âbirîne tecâvüz etmek gibi cerâim- $i$ adiyede bulundukları ve jandarma mevcûdunun fikdanına ve livâ dâhilinde jandarma tabur kumandanından başka mektebli jandarma zâbiti bulunmamasına ve efrâd yedindeki eslihanın eşkıyâ yedlerindeki eslihaya fâik olmamasına binaen eşklyâ-yı merkûmenin der-dest ve tenkîlleri mümkün olamamaktadır.

Gürün Kazâsı: Gürün kaymakamlı̆̆ından alınan telgraf-nâme-i cevâbiyyede Gürün Kazâsı mıntıkasında adi ve siyâsî eşkıyâ çetesi yok ise de kazâ-yı mezkûrun Elbistan'la hem-hudud olmasına binaen ara sira Elbistan soyguncuları bazen Gürün mıntıkasına tecâvüz etmekte olduklarından bu kabîl tecâvüzâtın vuku'unda mütecâvizlerinin der-dest ve tenkîli için karakol kumandanlıklarının muktedir başçavuş veya çavuşların uhdesine tevdîi beyân ve teklîf edilmişdir.

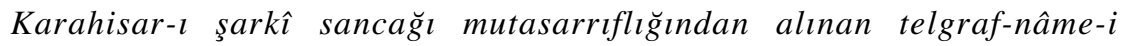
cevâbiyyede Karahisar-ı şarkî livâsı mıntıkasında adi ve siyâsî eşkıyâ çeteleri olmadı $\breve{g}$ bildirilmiştir.

Temin-i inzibât için Sivas Jandarma Alayı Kumandanlı̆̆ından Alınan tezkere-i cevâbiye Hulâsası

Jandarma zâbitân hesab memurluğu ve efrâd kadrolarının ikmâl ve maşâtının tezyîdi, efrâd aileleri iaşelerinin temini ve vilâyet mümtedd telefon tellerinin tamiri ve $\hat{\imath} c \hat{b} b$ eden mahallere yeniden telefon güşâdı jandarmalarda mevcûd eslihanın küçük çaplı mavzerlerle tebdîli ve levâzım-ı iksâiyenin temin ve i'tası ta'lîm ve terbiye için jandarma efrâd mektebinin güşâdı ve bunların ikmâline kadar Amasya taburuna altı yüz mevcûdlu bir nizâmiye taburunun i’tası ve jandarma zâbitânının alacă̆̆ emir üzerine icra idece ği tedâbîrden dolayı muâheze edilmemesi esbâbının temini bildirilmiştir.

Hıdırnallı Nâhiyesi: müdüriyetinden alınan tahrîrât-ı cevâbiyyede nâhiyesi dâhilinde siyâsî ve adi çeteleri olmadı̆̆̆ .

Ulaş Nâhiyesi: müdüriyetinden alınan tahrîrât-l cevâbiyyede nâhiyesi dâhilinde siyâsî ve adi çeteleri olmadı̆̆

Ilbeğlü Nâhiyesi: müdüriyetinden alınan tahrîrât-l cevâbiyyede nâhiyesi

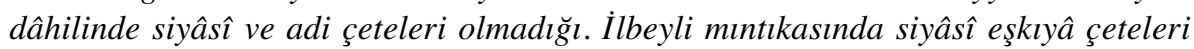
yok ise de ara sıra üç beş kişiden mürekkeb adi çeteler zuhur etmekte ve bazen 
ahali-i kurâya tecâvüz olunmakda ... jandarma kadrosunun ikmâlinde bunların da der-dest ve tenkîlleri mümkün olmayacă̆ bildirilmiştir.

\section{Eşkıyâ-yı Merkumun der-dest ve tenkîlleri için ittihazı lazım gelen tedâbîr}

Erbaaa Kazâsı mıntıkasında mevcûd jandarma karakolhanelerinin tezyîdi ve Erbaa Jandarma Bölü̈̆ü mevcûduna üç zâbitle yüz on bir piyâde ve kır iki süvari neferinin ilavesi ve Erbaa Kazâsıyla hem-hudud bulunan bazı nevahi merkezlerinde karakolhane tesis olunmak üzere dört bölükten ibaret bulunan Tokad Jandarma taburunun beş bölü̆ge iblăğ ve hiç olmazsa bölük kumandanlarının behemehal mektebli olarak yeniden zâbit celbi ve jandarmalar nezdindeki eslihanın küçük çaplı mavzerlerle tebdîli teklif ve beyân edilmiştir.

Yenihan Kazâsı: müdüriyetinden alınan tahrîrât-ı cevâbiyyede kazâ dâhilinde el- yevm siyâsî eşkıyâ çeteleri olmayub yalnız bazen Zile ve Maden kazâları mıntıkasına giderek soygunculuk yapmakta ve efrâdı dört beş kişiden ibaret olan Yeniköylü Kara Mustafa Çetesi var ise de ahiren Amasya hududuna geçmiş olduğu ve kazâ âsâyişinin be-hakkı temin ve istikrarı için kazâ jandarma kadrosunun ikmâline muvaffak bulunduğu bildirilmiştir.

Hafik Kazâsı: Kaymakamlıktan alınan tahrîrât-ı cevâbiyyede Hafik Kazâsı dâhilinde tehcirden avdet etmiş olan Ermenilerden mürekkeb yirmi beş ve otuz kişiden müteşekkil bir eşkıyâ çetesi mevcûd olduğu ve ara sıra mârrin ve âbirîne tecâvüz ve nukud ve eşyalarını gasb etmekte olduklarl ve geçenlerde Gökdepe civarında bir postaya taarruz ederek elli bin kuruşu mütecâviz emaneti ahz ve gasb ve efrâd-ı müstebdeleden beş kişiyi Cancik ile Zara arasında sûret-i fecîde katletmiş oldukları ve bunlara civar kurâ ahalisinden bazı İslamların yataklık ettiğ $i$ ve eşirrây merkûmenin der-dest ve tenkîli kazâ jandarma kadrosunun ikmâliyle beraber yerli bulunan bil-umûm jandarmaların tebdîli teklif ve beyân edilmiştir.

Darende Kazâsı: Darende Kazâsı dâhilinde eşkıyâ-yı müstemirreden kimse yok ise de kazâ jandarma mevcûdunun ara sıra zuhur eden cerâim-i adiye fâillerini der-

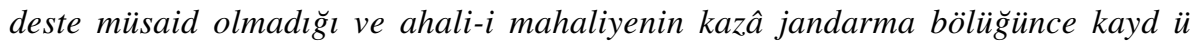
kabül edilmemekte olması hasebiyle kuvvet tezyîd edilemediğinden jandarma kadrosunun be-heme-hâl ikmâli muktezi bulunduğu beyân ve teklif edilmiştir.

Tenos Kazâsı: kaymakamlı̆̆ından alınan cevâb-nâmede Bŏgazlıyan kazâsının Çat karyesi ...da tahassun eden elli kişiden mürekkeb DesmoEylik'in riyâseti tahtında bir Ermeni çetesi mevcûd olub siyâsî bir maksada müstenid değil ise de ara sıra Tenos Kazâsına merbut kurâ ahalisine tecâvüz ve taarruz etmekde olduklarından der-dest ve tenkîlleri için birkaç defa müteaddid mahallerde müfrezeler tahrik edilmiş ise de tahassun-gâhları orman gayet sarb olmasına binaen bir muvaffakıyet istihsal olunamayarak el-yevm vadi-i şekavetde olduklart.

Divrĭgi Kazâsı: Kaymakamlı̆̆ından alınan cevâb-nâmede Divrĭ̆i Kazâsı dâhilinde siyâsî çete olmayub Zara Kazâsı'nın Karacaviran karyesinden Kasım Oğlu Ísmail ve Süleyman oğlu İzet ve Divrik'in Hamuç karyesinden Ali oğlu Ali ve 
Ziver Naci Hüseyin ve üç dört refikasıyla Zara-Divriği-Torbaçay kazâları arasında icra-yı şekavet etmekte olub der-dest ve tenkîlleri için yirmi mevcûd bir müfreze tahrik edildiği.

Kangal Kazâsı: kaymakamlı̆̆ından alınan telgraf-nâme-i cevâbiyyede Kangal mıntıkasında adi ve siyâsî eşkıyâ çeteleri olmadı̆̆ı.

11 Haziran 1335 tarihinden 26 A ğustos 1335 tarihine kadar Sivas Vilâyeti dâhilinde der-dest edilen eşkıyâ ve ceraimin listesidir

\begin{tabular}{|c|c|c|c|c|}
\hline Siğınan-adet & & Hayyen & Meyyiten & Toplam \\
\hline 2 & Islâm & 257 & 19 & 276 \\
\hline 0 & Ermeni & 9 & 2 & 11 \\
\hline 12 & Rum & 15 & 9 & 24 \\
\hline & & & & \\
\hline 14 & & 281 & 30 & 311 \\
\hline
\end{tabular}




\section{EK:II}

TİTE Arşivi K.16 G.83 B. 83

\section{Dâhiliye Nezâreti Celîlesine şifre}

Sivas'a muvâsalat-ı teberrük-ânemde beri geçen on dört gün zarfinda vukû' bulan tahkikât ve istılâât-ı aciz-âneme istinâden Sivas dâhilinde bugünün en mühim meselesi olan âsâyiş ve inzibât hakkında nazar-ı dikkat-i âsaf-ânelerini celb etmek vazife-i memuriyet lâzıme-i hamiyyet add ettim ara sıra eksik olmayan mülhakât-l sairede vukûât-ı adiyeden âsâyiş en ziyâde bozuk olan mahal Amasya sancă̆ıdır. Bu livânın müstakil Canik sancă̆ıyla hem-hudûd olmasından dolayı müteaddid siyasi Rum çeteleri mevcûd olduğu gibi bunlara mukabil müsellah asker kaçaklarlyla müteşekkil İslam çeteleri de vardır. Katl-i nüfus, gasb ve garet, kutta'-üt-tarîklik, dağa adam kaldırmak, ya kasden yahud lâ-kaydilik yüzünden hapishanelerden firâr bu livâ için vukuât-ı rûz-ı sıradandır. Asâyiş ve inzibâtın teminiyle hadisât-ı mümâseletin izâlesi hakkında cihet-i mülkiye ve askeriye şimdiye kadar ittihâz-l tedâbirde ihmal ve tekâsül vuku'u gayr-i münkir olmakla beraber bu halin devam edip gitmesine en ziyâde sâik olan şey vesâit-i inzibâtiye ve ta'kîbiyenin keyfiyet ve kemiyyetçe noksan oldu ğuna kanâat-ı kâmile hasıl ettim. Beş on günden beri tahaddïs eden vak'a-yı şekavet-kârâne mütecâsirlerin ta'kîb ve der-destleri için vuku' bulan tebligâta karşı jandarma kadrosunun noksan ve mevcûd efrâdın emr-i takibde kayıtsızlıkları ve iki üç aydan beri maaş alamamalarından mütevellid inkisâr-l şevkleri ileri sürülerek salâhiyet-dâran tarafindan cevab verilmiş bunun en bâhir delili vilâyet jandarma alayı kadrosu esası itibariyle 1452 piyâde ve 480 süvariden ibaret olup bu günkü mevcûdu ise 926 piyâde ve 350 süvariden ve bunların kısm-ı a'zamîde hiçbir işe yaramayan bakayâ ve firârî efrâd ile kısmen gönüllülerden ibarettir. Bu mevcûdun hapishane ve posta muhafızlı ̆̆l vezâif-i taharriye gibi hidemâtı-ı müteferrik mikdarı tenzîl olunduğu takdirde mevcûd 523 piyâde ve 205 süvariye maksûr kallyor ki arz ettiğim kabiliyetde bulunan bu mikdâr efrâd ile __ nüfus 3 livâ, kazâ ve nâhiyeleri hâvî bir vilâyetin temini inzibât ve âsâyişi ne sûretle kabil ve ne dereceye kadar kabil olabileceğ i şâyân-l teemmüldür. Kadro tamam olsa ahvâl-i tabîiyyede belki mümkündür. Fakat bir taraftan açlığın diğer taraftan türlü türlü âmâl ve maksadla kargaşalıktan istifade etmek isteyen muhtelif amillerin tesiriyle şirazeden çıkarak fevk-al-âdelik kesbetmiş olan mahallerde bu kadro ile iş görülmek kabil değildir nisbeten hal-i sukûn ve âsâyişin bulunduğu zan olunan Kastamonu, Ankara, Konya gibi civar vilâyetlerden alınacak kıymetli efrâd ile kadro ihtiyaç derecesinin ve ... işe yarar zâbitân ve efrâd tedârük olunabilmek için maaşlarının mâh ve mâh i'tası temin edilir ve yahut kadronun tevsî'i kabil değilse hâl-i hâzırda noksanın ikmâli için ve zâbitân maaş meselesi temin edilmekle beraber ta'kîb işlerinde meleke kesbetmiş muktedir zâbitler kumandasında tam mevcûdlu iki bölük asker sûret-i daimide jandarmaya kuvvet-üzzahr olarak ilaveten tayin.....ise âsâyiş meselesinin başarlabileceğini ve aksi takdirde vesâit-i hâzıra ile hiçbir şey yapılmak imkanı olmadı̆̆ını anladım. Arz ettiğim asker meselesi için kolorduya veyahud mülhakâtdaki firkalara müracâ̂t 
hususu varid-i hatır olursa da askerin terhisinden dolayı bunların mevcûdu lâ-şey hükmünde olduğu gibi şimdiye kadar mevcûdiyetinden hiçbir istifade temin edilemediği bugünkü hal ile meydanda bulunuyor ki buralardan fazla bir şey beklemek fikrimce abes olur. Binâen-aleyh ma'rûzâtımı layı olduğu ehemmiyetle telakki buyurarak mesâib-i harbiyyeden zaten müteessir ve mutazarrır olan ahalinin mal ve can ve namuslarının muhafazası çaresinin bir an evvel istikmâli zımnında icâb edenlere emr-i kat'i verilmesini ilcâ-yı maslahatla sûret-i mahsûsada arz ve istirhâm eylerim.

26 Haziran 1335 
